\title{
The comparison of several soil cultivation methods in the Tokaj-wine region
}

\author{
Göblyös, J. \& Ulcz, A. \\ Corvinus University of Budapest, Department of Viticulture
}

\begin{abstract}
Summary: Our results show that the different cultivation methods have higher effect on the yield than on the grape quality. In 2007 the weather was extreme dry (from May to August only $195 \mathrm{~mm}$ precipitation was recorded) the straw mulch proved to be the best solution regarding the yield and the grape quality. Although no significant differences were observed in the sugar- and titratable acidity content of the must, the ratio of noble rotted berries was higher on the straw mulched plots. Straw mulch could conserve the moisture content of the soil and it seems to be contributed to the conformation of suitable microclimate for Botrytis infection, but for long distance conclusions further examinations need to be investigated. The less yield and ratio of rot was observed in case of barely covered vines and the vegetative growth of the grape was less intensive in case of these vines.
\end{abstract}

Key words: soil cultivation, grape, Botrytis

\section{Introduction}

Soil cultivation is one of the most important questions of the agriculture. It has an effect not only on the soil, but indirectly on the plants as well. Therefore it is really relevant to choose the proper cultivation method. Also in case of integrated farming is advanced to apply these environment friendly methods.

In case of vineyards is the soil cultivation also important, especially when the plantation is located in steep slopes. Such kind of erosion, which can be caused by heavy rainfalls or also by frequent mechanical soil cultivation, is a major problem. So soil cultivation method has to be chosen considering this.

A suitable soil cultivation method improves the soil structure: compaction, erosion, nutrient losses can be reduced. It makes better conditions in the soil environment for the existing soil organisms, as follows it increases soil biological activity and the organic matter content of the soil can be preserved. The moisture content of the soil depends also on the cultivation method. The preservation of soil moisture is especially important, in that kind of areas where the precipitation is less than $500 \mathrm{~mm}$ / year and principally from June to August, when the evapotranspiration is greater than the precipitation, like in Hungary (Bauer et al., 2004). The growth of the roots is influenced by the structure of the soil; hereby the growth of the grape is related to the compaction and to the moisture content of the soil, too. The looser the soil is the longer the roots of the vine are (Wheaton et al., 2007). Nutrient uptake of the grape is affected by the soil compaction, the moisture content and the soil temperature. For example between the high soil temperature and $\mathrm{N}, \mathrm{K}, \mathrm{Ca}, \mathrm{Mg}$ uptake is a positive correlation (Bogoni et al.,1995). Several abnormal circumstances in the soil, for example lack of water can cause stress on the plants, which influences the growth and the yield of the plants negatively (Fardossi, 2001).

One of the most often used soil cultivation methods in vineyards is mechanical cultivation. But when it is used too often or inadequate negative effects can be observed: decaying soil structure, erosion, nutrient losses, dry soil affected by greater evapotranspiration (Bauer et al., 2004). Mechanical soil cultivation resultes-through the long term traffic- topsoil and subsoil compaction below the frequent tillage depth (Ferrero et al., 2005).

Covering methods are ecological soil management techniques. As soil covering several materials or cover crops can be used.

Straw mulch is a relatively cheap and easy available material. Application of mulch has a lot of agronomic advantages, including the control of weeds and erosion, improvement in soil physical structure. The presence of mulch eliminates the need for frequent soil tillage in agroecosystems. It prevents the soil like an umbrella by heavy rainstorms $(S c h u c h, 1981)$. The prevention of the soil is important, because the soil moisture in the whole profile depend primarily on the intensity of rainfall, not on the total amount of it. At high intensities soil moisture increases only in the surface layer, but no significant increases were observed in deeper layers, where most of the roots are found. Under low intensity rainfalls, the increase in soil water content occurred in the whole profile (Ramos et al., 2006). The water budget of the soil improves due to the better structure and the straw reduces water loss by evaporation. It enhances the soil environment for existing soil organisms by 
improving soil nutrient availability and reducing soil temperature fluctuations (Jacometti et al., 2007). When the straw decays it adds nutrients to the soil, but because its $\mathrm{C}: \mathrm{N}$ ratio is wide, additional $\mathrm{N}$ is needed. Otherwise the lack of $\mathrm{N}$ causes pentosan effect $(F o x, 1981)$.

Beside straw or other mulch materials, several crops can be used. Permanent or only in certain seasons covering crops, legumes or non legumes are appropriate to cover the soil between the rows. Cover crops compete with weeds, prevent erosion and soil compaction and in addition, they increase the complexity of agroecosytems. The soil structure and soil biological activity will improve. They facilitate to filter the water into the soil. It has an effect on the nutrient content of the soil, especially when a leguminous plant is used, because of the biological fixation of atmospheric N (Bauer et al., 2004). Cover crops have also negative effects on the vine performance; compete for water and nutrients in the soil with vine. Places, where precipitation is not high enough are not suitable for permanent cover crops, because of the great use of water. In this cases grapes are stunted, lower wine performance can be observed. The vegetative growth is reduced, but it can have also positive effects. Because of the lower canopy density, the microclimate of the plantation will change, the vapor content of the air will be lower, and because of this the infection of the grape with fungal diseases, for example Botritys cinerea, is reduced (Monteiro et al., 2007). In some cases it can be disadvantageous, for example in the Tokaj wine region of Hungary, where the noble rot of the berries caused by Botritys cinerea is important to gain Aszú wine. Infection of Botritys requires moist conditions, but later for the rotting period, it needs drier climate. If the weather stays wet, grey rot of the bunches can be observed (Lehoczky, 1968). There is an increased light penetration in the thin canopy, so the titratable acidity of the berries can be reduced and the sugar content will improve (Ingels et al., 2005).

\section{Materials and methods}

The experiment was set up in the Tokaj-wine region in 2007. Three soil cultivation methods were compared: mulching with straw, barely cover crop (Hordeum vulgare $L$. convar. vulgare $M S F$.) and mechanical cultivation. The study was carried out on Royat cordon vines (with $1 \times 1,8 \mathrm{~m}$ row and vine spacing). The investigated varieties were: 'Furmint' clone T.85 and 'Hárslevelü' clone K.9 grafted in Teleki 5.C. rootstocks. Every treatment is located in five rows, in four replications per treatment. The plantation is settled in a steep-slope area on loess soil in the site of Hétszôlô (Hárslevelû) and Nagyszốlổ (Furmint), where is the prevention of erosion is specially important.

The yield, the sugar content, the titratable acidity, the $\mathrm{pH}$ of the juice were measured in case of both cultivars and the ratio of noble rot within one bunch were recorded in case of 'Furmint' cultivar.

\section{Results}

Comparing the yield and the average bunch weight on the plots, significant differences could be observed in case of both varieties. The highest average bunch weight (Fig.1) was measured in case of the straw mulched grapes $(0.15 \mathrm{~kg}$ 'Hárslevelű', $0.22 \mathrm{~kg}$ 'Furmint'), while the minor average bunch weight was measured on the barely covered grapes $(0$. 68 kg -'Hárslevelũ', 1.27 kg -'Furmint'). The greater yield (Fig. 2) on straw mulched grapes $(0.78 \mathrm{~kg} / \mathrm{vine}$ - 'Hárslevelü', $1.75 \mathrm{~kg} / \mathrm{vine}$ - 'Furmint') the less (0.69 kg/vine 'Hárslevelü', 1.27 kg/vine -'Furmint') on the barely covered plots was measured in case of both varieties.

In case of the 'Furmint' variety the ratio of noble rot within one bunch was also measured (Fig. 3). From every treatment 50 randomly selected bunches was observed in four replications per treatment. The percentage of the rotted, Botrytis infected berries was counted within the bunches. The more rotted berries were by the bunches from straw mulched plots observed $(7.37 \%$ of the bunch) and the grapes from the barely covered rows contained the less infected berries (3.6\% of the bunch).

The $\mathrm{pH}$, the titratable acidity and the sugar content of the must was measured. Comparing this values no significant differences were observed in the yield of the investigated treatments (Table 1 ).

Regarding the pruning weights (recorded in February of 2008) it can be established that the less intensive vegetative growth was on the barely covered plots recorded (Fig. 4).

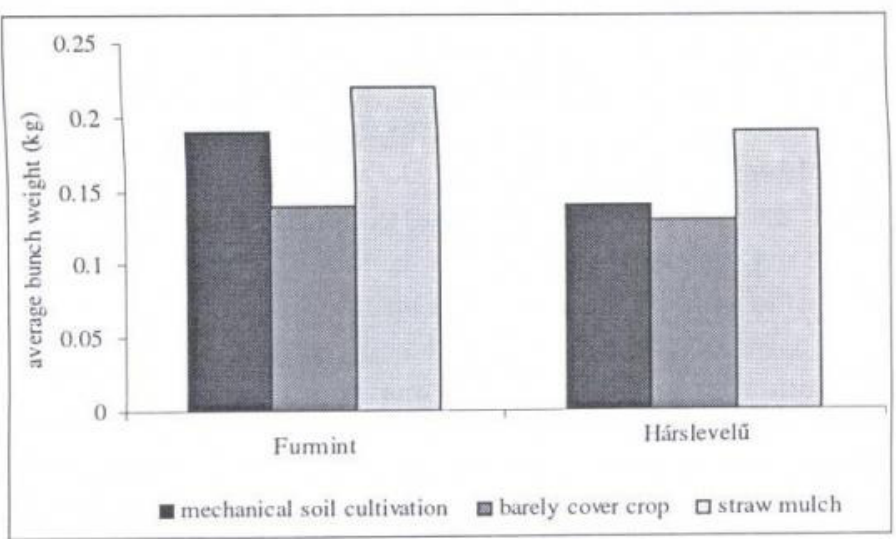

Figure 1 Average bunch weight of Furmint and Hárslevelü (Tokaj, 2007)

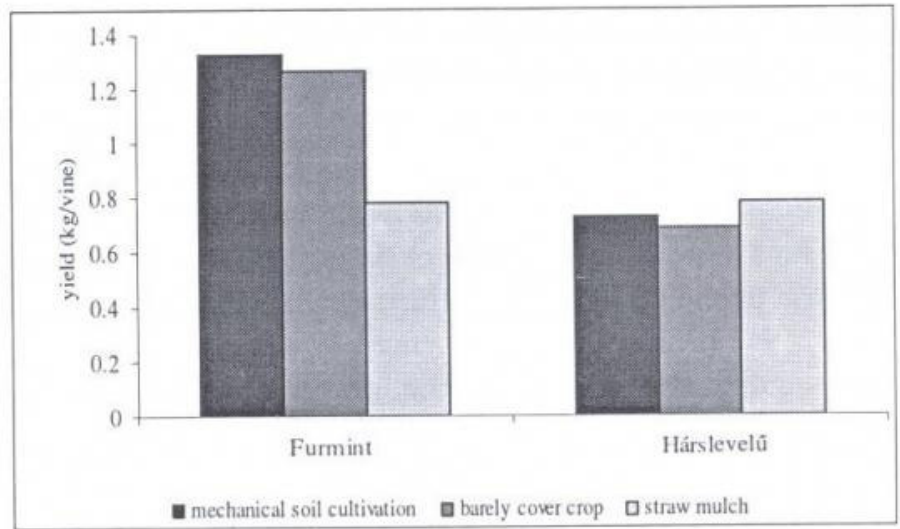

Figure 2 The yield of Furmint and Harrslevelü (Tokaj, 2007) 


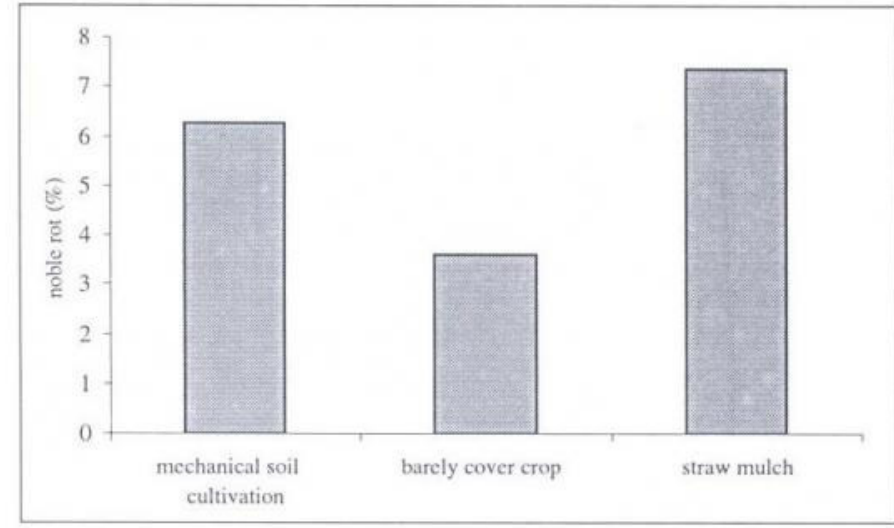

Figure 3 Ratio of noble rot within one bunch in case of Furmint (Tokaj, 2007)



Figure 4 The pruning weights of Furmint and Hárslevelü (Tokaj, 2008)

Table 1 The main parameters of the must of Furmint and Hárslevelú (Tokaj, 2007)

\begin{tabular}{|c|c|c|c|c|c|c|}
\hline \multirow{3}{*}{$\begin{array}{l}\text { Measureds } \\
\text { parameters }\end{array}$} & \multicolumn{6}{|c|}{ Varieties } \\
\hline & \multicolumn{3}{|c|}{ Furmint } & \multicolumn{3}{|c|}{ Hárslevelũ } \\
\hline & $\begin{array}{l}\text { mechanical } \\
\text { cultivation }\end{array}$ & $\begin{array}{c}\text { barely } \\
\text { cover crop }\end{array}$ & $\begin{array}{l}\text { straw } \\
\text { mulch }\end{array}$ & $\begin{array}{l}\text { mechanical } \\
\text { cultivation }\end{array}$ & $\begin{array}{c}\text { barely } \\
\text { cover crop }\end{array}$ & $\begin{array}{l}\text { straw } \\
\text { mulch }\end{array}$ \\
\hline $\mathrm{pH}$ of the must & 3,18 & 3,16 & 3,2 & 3,12 & 3 & 3,09 \\
\hline Sugar content of the must ( ${ }^{\circ}$ Brix) & 22,88 & 23,2 & 6,92 & 25,39 & 25,45 & 25,64 \\
\hline Titratable acidity of the must $(\mathrm{g} / \mathrm{L})$ & 7,32 & 6,92 & 7,6 & 6,95 & 6,4 & 7,15 \\
\hline
\end{tabular}

\section{Conclusions}

Our results show that the different cultivation methods have higher effect on the yield than on the grape quality. In 2007 the weather was extreme dry (from May to August only $195 \mathrm{~mm}$ precipitation was recorded) the straw mulch proved to be the best solution regarding the yield and the grape quality. Although no significant differences were observed in the sugar- and titratable acidity content of the must, the ratio of noble rotted berries was higher on the straw mulched plots. Straw mulch could conserve the moisture content of the soil and it seems to be contributed to the conformation of suitable microclimate for Botrytis infection, but for long distance conclusions further examinations need to be investigated. The less yield and ratio of rot was observed in case of barely covered vines and the vegetative growth of the grape was less intensive in case of these vines.

\section{References}

Bauer, K., Fox, R. \& Ziegler, B. (2004): Moderne Bodenpflege im Weinbau. Österreichischer Agrarverlag, Leopoldsdorf.

Bogoni, M., Panont, A., Valenti, L. \& Scienza, A. (1995): Effects of soil physical and chemical conditions on grapevine nutritional status. Acta Horticulturae 383: 299-303.

Fardossi, A. (2001): Einfluss von Stressfaktoren auf die Weinrebe. Der Winzer. 2: 11-12.
Ferrero, A., Usowicz, B. \& Lipiec, J. (2005): Effects of tractor traffic on spatial variability of soil strength and water content in grass covered and cultivated sloping vineyard. Soil Tillage and Research. 84: 127-138.

Ingels, A.C., Scow, K.M., Whisson, D. A. \& Drenovsky, R.E. (2005): Effects of cover crops on grapevines, yield, juice, composition, soil microbial ecology, and gopher activity. Am. J. Enol. Vitic. 56. (1): 19-30.

Jacometti, M.A., Wratten, S.D. \& Walter, M. (2007): Management of understory to reduce the primary inoculums of Botrytis cinerea: Enhancing ecosystem services in vineyards. Biological Control. 40: 57-64.

Lehoczky-Reichart (1968): A szổlổ védelme. Mezổgazdasági Kiadó Budapest

Monteiro, A. \& Lopes, C.M. (2007): Influence of cover crop on water use and performance of vineyard in Mediterranean Portugal. Agriculture, Ecosystems and Environment. 121: 336-342.

Ramos, M.C. \& Martínez-Casanovas, J.A., (2006): Impact of land leveling on soil moisture and runoff variability in vineyards under different rainfall distributions in a Mediterranean climate and its influence on crop productivity. Journal of Hydrology. 321: 131-146.

Schuch, M. \& Jordan, F. (1981): Ergebnisse zehnjahriger Erosionsschutzversuche im Steillagenweinbau in Franken. Der Deutsche Weinbau. 25/26: 1081-1082.

Wheaton, A.D., McKenzie, B.M. \& Tisdall, J.M. (2007): Management to increase the depth of soft soil improves soil conditions and grapevine performance in an irrigated vineyard. Soil Tillage Res. 